\title{
Eventive and stative passives and copula selection in Canadian and American heritage speaker Spanish
}

\author{
Elena Valenzuela ${ }^{1}$, Michael Iverson ${ }^{2}$, Jason Rothman ${ }^{3}$, \\ Kristina Borg ${ }^{1}$, Diego Pascual y Cabo ${ }^{4}$ and Manuela Pinto ${ }^{5}$ \\ ${ }^{1}$ University of Ottawa / 2 Macquarie University / ${ }^{3}$ University of Reading / \\ ${ }^{4}$ Texas Tech University $/{ }^{5}$ Utrecht University
}

\begin{abstract}
Spanish captures the difference between eventive and stative passives via an obligatory choice between two copula; verbal passives take the copula ser and adjectival passives take the copula estar. In this study, we compare and contrast US and Canadian heritage speakers of Spanish on their knowledge of this difference in relation to copula choice in Spanish. The backgrounds of the target groups differ significantly from each other in that only one of them, the Canadian group, has grown up in a societal multilingual environment. We discuss the results as being supportive of two non-mutually exclusive explanation factors: (a) French facilitates (bootstraps) the acquisition of eventive and stative passives and/or (b) the US/Canadian HS differences (e.g. status of bilingualism and the languages at stake) is a reflection of the uniqueness of the language contact situations and the effects this has on the input HSs receive.
\end{abstract}

Keywords: copula, heritage speakers, ser, estar, bilingualism, syntax, passives

\section{Introduction ${ }^{1}$}

The present study adds to the growing body of formal linguistic studies on heritage language acquisition (see Benmamoun, Montrul \& Polinsky, 2013 for review) by examining knowledge of the stative and eventive passives in Spanish as a heritage language, inclusive of differences in their distribution and copula selection

1. The following abbreviations have been used: be (SER for Spanish 'ser' and be (ESTAR) $_{\text {for }}$

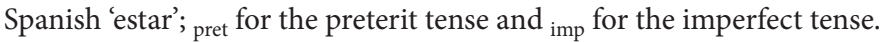


properties. In doing so, we follow the work by Bruhn de Garavito and Valenzuela $(2006,2008)$ for adult L2 acquisition of Spanish. We test, compare, and contrast two sets of Spanish heritage speakers (HS henceforth). These groups come from the USA and Canada respectively. As such, English is shared in both contexts as the native majority language of the greater society and is the dominant language of both groups of HSs. Crucially, the backgrounds of the target groups differ significantly from each other in that only one of them, the Canadian group, has grown up in a societal multilingual environment. Not only does such an environment provide exposure to and formal education in a third language (i.e. French), but the fact that the additional language is a Romance language may provide extra benefit to Canadian HSs. Comparing two groups of HSs with the variables that make them similar and distinct in the way we do here is, to our knowledge, unique and contributes to this area of study in non-trivial ways. Bringing these groups together will allow us to test the extent to which multilingualism brings something to bear on competence outcomes for the heritage language and also the role that structural similarity between the heritage language and one of the societal languages plays in heritage language competence in certain domains of grammar.

A heritage language is a minority language spoken in an environment where it is not the/a language of the majority population. HSs are bi- or multilinguals who grow up as members of a given minority ethnolinguistic community and either receive heritage and the majority (or more) language input (simultaneously) from birth or receive heritage language input exclusively until school age (see e.g., Montrul, 2008; Rothman, 2009). In both cases, the starting point of formal education in the societal language correlates to a sharp quantitative decrease in whatever amount of heritage language input HSs received prior to this onset. Usually, by late childhood, HSs have become dominant speakers of the majority community language and their knowledge of the heritage language varies from individual to individual. And so, despite the fact that the heritage language is acquired naturalistically in early childhood and is, thus, a native language (cf., Rothman \& Treffers-Daller, 2014), HSs' end-state grammars most oftendiffer from that of monolingual native speakers, sometimes quite dramatically so (e.g., Montrul, 2004, 2008; Polinsky, 2007, 2008, 2011).

There have been several proposals that attempt to account for, if not explain, how childhood naturalistic acquisition can differ in ultimate attainment knowledge as exemplified by the resulting grammars of monolingual and HSs of the same language. For example, Montrul (2008) argues that HS bilinguals are incomplete learners of their heritage language, at least by means of comparison to monolinguals. Putting aside the obvious "comparative fallacy" in the sense of Bley-Vroman (1983), which no one denies, the proposal intends to convey the idea that there is the possibility of stunted or arrested development in the heritage 
language. In other words, a byproduct of the shift in dominance that characterizes HS bilingualism and occurs at an early age results in differences in developmental course between HSs and monolingual children. Although they both acquire the same language, the development of the HS is affected by influence of the societal majority language and other processes that can be linked to their bilingualism and bilingual learning experience. These other processes can include attrition of properties which were acquired at some point in the course of heritage language acquisition but became eroded by adulthood (e.g., Polinsky, 2011), differences in education and literacy in the heritage language (e.g., Pascual y Cabo \& Rothman, 2012; Rothman, 2007), L1 attrition effects to the first generation input providers which change the qualitative shape of the input to which HSs are exposed (e.g., Pires \& Rothman, 2009; Sorace, 2004), various general effects of bilingualism (Kaltsa, Tsimpli \& Rothman, 2012; Sorace, 2011) and others. Whether or not the term incomplete acquisition should be used as the catch-all term for all HS differences from a monolingual baseline - thus encompassing, in addition to true arrested development, all of these other factors - or even at all (see Pascual y Cabo \& Rothman, 2012), is not of major concern herein. It is likely that all the aforementioned factors play a role in at least some of the differences attested in the HS literature. Regardless of which applies for any given domain, we all can agree that HS "grammatical knowledge" is strikingly different from monolinguals. Furthermore, it is largely uncontroversial to claim that the majority language exercises some influence on the heritage language, although the degree to which this occurs is subject to debate.

Following from this general line of reasoning, one question worth pursuing is whether or not there are limits on majority/minority language influence depending on linguistic and extra-linguistic variables idiosyncratic to a given context. In other words, in the prima facie example of Spanish as a heritage language in a majority English-speaking environment, will English always exercise the same level and type of influence on Spanish? To pursue this question, one can compare the same majority/heritage language pair in a context where linguistic and extra-linguistic factors are different. Such is the relationship between Spanish as a heritage language in the US and Canada. Whereas the United States has one societal language, Canada has two: French and English. It is not unusual, therefore, for a Spanish heritage speaker in Canada to be raised in a multilingual community language environment and be competent in the heritage language as well as a balanced French/English speaker. In the case of Ontario (a predominantly English-speaking province which borders Québec, the French-speaking province) French is the minority language while English is the majority language. In each province, however, regardless of the majority language, parents have the option to place their children in either a French or an English language program 
in the formal education system. At present, over 1,890,000 Canadian students are studying French through the core/basic or immersion programs in the predominantly English-speaking part of Canada. The Canadian-Spanish HSs in this study are educated in both English and French and are very proficient speakers of both languages.

It is well documented that English influences the Spanish of HSs in the US (e.g., Beaudrie \& Fairclough, 2012; Montrul, 2008; Silva-Corvalán, 1986, 1994; among others). Much less studied is the case of Spanish as a heritage language in the context of Canada, and particularly where the Canadian environment truly supports both French and English as societal languages and languages of formal education. Does being a formally educated speaker of another Romance language, French, change the dimensions of differences to be expected in Canadian HSs of Spanish? We pursue this possibility in the remainder of this chapter by examining knowledge of stative and eventive passive structures in Spanish as a heritage language and the copulas they select respectively. Previous work by Silva-Corvalán (1986) has already shown differences in HS Spanish with copula choice in the context of the US, the question is whether we will show the same in our group of American HSs and the extent to which the Canadian and American HSs pattern together or differently. Whether these two HSs groups pattern together and understanding the consequences of whatever is shown will make significant contributions towards understanding more precisely the variables that condition HS grammatical knowledge.

\section{Stative and eventive passives}

English, French and Spanish differ from each other with respect to the way their grammars distribute copular verbs in passive voice constructions: although all three languages make a distinction between adjectival and verbal passives [those that denote states and events respectively (Levin \& Rappaport, 1986)], only in Spanish is this distinction made via verb choice. Consider Examples (1)-(3) below:

(1) a. The dinner is prepared by Teo

(eventive passive)

b. The dinner is already prepared (*by Teo)

(stative passive)

(2) a. Le souper est préparé par Pau

(eventive passive)

the dinner is prepared by Pau

b. Le souper est déjà préparé $\left({ }^{*}\right.$ par Pau $) \quad$ (stative passive)

the dinner is already prepared

(3) a. La cena es preparada por Kristina (eventive passive) the dinner is $(\mathrm{SER})$ prepared by Kristina 


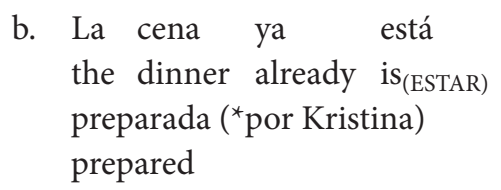

(stative passive)

As can be seen in the examples above, while English (1a-b) and French (2a-b) grammars use only one lexical item for both sets of constructions (to be and etre respectively), Spanish (3a-b) uses two options (ser and estar), with each one having a specific purpose: ser is used for eventive passives (as in 3a) and estar is used for stative passives (as in (3b)). As generally claimed in the literature on Spanish copular constructions, the distribution of Spanish copula is not random, but rather governed by the type of state being described and is not limited to the stative/eventive passive distinction. For example, it has been noted that in copula-adjective combinations, some adjectives combine exclusively with ser (e.g., inocente, capaz) while others combine exclusively with estar (e.g., muerto, desnudo). Interestingly, there is a third group of adjectives that can appear with both copulative predicates (e.g., listo, guapo, feo) but whose resultant meaning varies depending on the copula selected. Examples (4)-(6) below illustrate this.

(4) La chica $\left\{\right.$ es $/{ }^{*}$ está $\}$ inocente

'The girl is $\{$ SER/*ESTAR\} innocent'

(5) El rey $\left\{{ }^{*}\right.$ es/está $\}$ muerto

'The king is ${ }_{\left\{{ }^{*} \text { SER/ESTAR }\right\}}$ dead'

(6) Lizzie \{es/está\} guapa

'Lizzie $\left\{\right.$ is $_{\{\text {SER }\}}$ pretty (in essence)/is ${ }_{\left\{E_{S T A R}\right\}}$ (circumstantially) $\}$ pretty'

Although several theoretical accounts have been advanced to explain the observed phenomena (e.g., Falk, 1979; Luján, 1981; Vañó-Cerdá, 1982; Clements, 1988; Schmitt, 1992; Leonetti, 1994; Delbecque, 1997; Maienborn, 2005; Schmitt \& Miller, 2007; Camacho, 2012; Gumiel-Molina \& Pérez-Jiménez, 2012; among many others), it is generally accepted within the Generative framework that the ser/estar distinction is primarily based on the inherent lexical aspect of each predicate (e.g., Luján, 1981; Lema, 1992; Schmitt, 1992). Following Bruhn de Garavito \&Valenzuela (2008, pp. 324-325), we adopt an analysis of copula use that considers (i) that estar is a copulative auxiliary carrying aspectual features while ser is a copula with an unmarked aspectual value ${ }^{2}$ (e.g., Lema, 1992; Schmitt, 1992), (ii) that the participles that complement the copula also carry aspectual information

2. The assumption, therefore, is that syntactically and semantically speaking it is the same 'estar' in copular sentences and in adjectival passives, and, on the same 'ser' in copular sentences and in verbal passives. 
(+/- perfective) and check their features with the verb (e.g., Luján, 1981; Varela, 1992) and (iii) the ser/estar distinction involves a complex interaction of several modules of the grammar (namely, syntax, lexicon, semantics, and discourse/ pragmatics). According to Bruhn de Garavito and Valenzuela, "given that ser is unmarked, both perfective and imperfective participles will be possible without resulting in a clash. On the other hand, only perfective participles will be possible when the copula is estar" (2008, p.325).

Given this analysis, three main observations can be made. First, eventive (ser) passives include an implicit or explicit agent but stative (estar) passives do not (e.g., Varela, 1992). As a result of this difference, the use of a "by" phrase in stative passives results in ungrammaticality:

(7) a. La puerta de la celda estaba cerrada ( ${ }^{*}$ por el guardia)

b. La puerta de la celda fue cerrada (por el guardia)

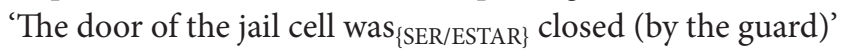

Second, eventive passives that describe past events tend to take the preterit as their canonical tense (Bruhn de Garavito \& Valenzuela, 2008). Stative passives, on the other hand, tend to take the imperfect:

(8) a. Cuando llegué, la comida \{fue/ when I-arrived the food $\left\{\right.$ was $_{\{\text {SER }\} \text { pret }} \mid$

\#era\} servida (por mi hijo)

\#was SERR\}imp $_{\text {S }}$ served (by my son)

b. Cuando llegué la comida

when I-arrived the food

\{estaba/ \#estuvo\} servida

$\left\{\right.$ was $_{\{\text {ESTAR }\} \text { imp }} /$ \#was $\left._{\{\text {ESTAR }\} \text { pret }}\right\}$ served (by my son)

'When I arrived, the food was served (by my son)'

One final property relevant to the present study is the interpretation of subjects conditioned on copula choice. The use of estar favors a specific interpretation of the sentential subject, with the predicate denoting a stage-level property, as in (6), or a perceptual report (in the sense of Roby, 2009), as in (9a). The use of ser is compatible with either a specific or generic interpretation of the subject, with the predicate denoting an individual-level (as in (6)) or kind-level (as in (9b)) property.

(9) a. Estar = specific interpretation of subjects

El salmón está delicioso

b. Ser = generic or specific interpretation of subjects

El salmón es delicioso

'Salmon is sSER/ESTAR\} $_{\text {delicious' }}$ 
Many theoretical accounts have been advanced to explain the observed phenomena (e.g., Falk, 1979; Luján, 1981; Vañó-Cerdá, 1982; Clements, 1988; Schmitt, 1992; Leonetti, 1994; Delbecque, 1997; Maienborn, 2005; Schmitt \& Miller, 2007; Gumiel-Molina \& Pérez-Jiménez, 2012; among many others), and it is generally accepted within the Generative framework that the ser/estar distinction is an aspectual one (e.g., Luján, 1981; Schmitt, 1992; Lema, 1992). More recent accounts (Camacho, 2012; Zagona, 2012, 2013) claim that the relevant features are ones tied to situation/lexical aspect: unlike ser, estar has certain inherent aspectual features which must be checked and deleted by its complement, while ser has no such features. Here, we take the relevant feature to be an event boundary feature, given the observation that "only verbs with endpoints can occur as adjectival participles with estar" (Zagona, 2013, p. 319).

The requirement of estar to check its boundary feature has syntactic and semantic consequences that give rise to the observations noted above ${ }^{3}$. Participial complements of estar are adjectival (Carrasco, 2006; Zagona, 2013) and denote states. True verbal passives - those that denote events and can accommodate a 'by' phrase - contain additional syntactic structure and/or aspectual features (e.g. an additional event boundary or Zagona's, 2013 path feature) that either clash with or prohibit checking of the boundary feature of estar; subsequently, they are only compatible with ser. Following Camacho (2012), complements that can occur with both ser and estar have two lexical entries, one containing the relevant aspectual features (for use with estar) and the other with none; complements that can only occur with one copula or the other have only one lexical entry. Complements compatible with the aspectual feature of estar are subject to certain interpretations in which the aspectual boundary denotes a contrast of an entity with itself (i.e., a stage-level interpretation) or of an entity/situation with other similar entities/situations (i.e., the interpretation of a subject as specific). Finally, as complements of estar are stative in nature, they tend to co-occur with imperfect forms in Spanish, while eventive passives with ser (which can contain full event structure and multiple event boundaries) are more likely to occur with preterit forms.

French is one of many languages that exhibit an alternation of 'have' and 'be' as auxiliary verbs in periphrastic verbal constructions. Cross-linguistically, 'have' typically occurs with transitives and unergatives, and 'be' occurs with unaccusatives, seen below in French.

3. While follow others in claiming that complements of estar must have some boundary feature (likely [+telic]), we do not take this to mean that the complex predicate (estar + complement) is bounded in the same way. It is possible that the boundary feature is interpreted as a telos in the active voice (e.g. 'He died') and as inchoation of a state (cf. Camacho, 2012) in the passive (e.g. 'He is dead'). 


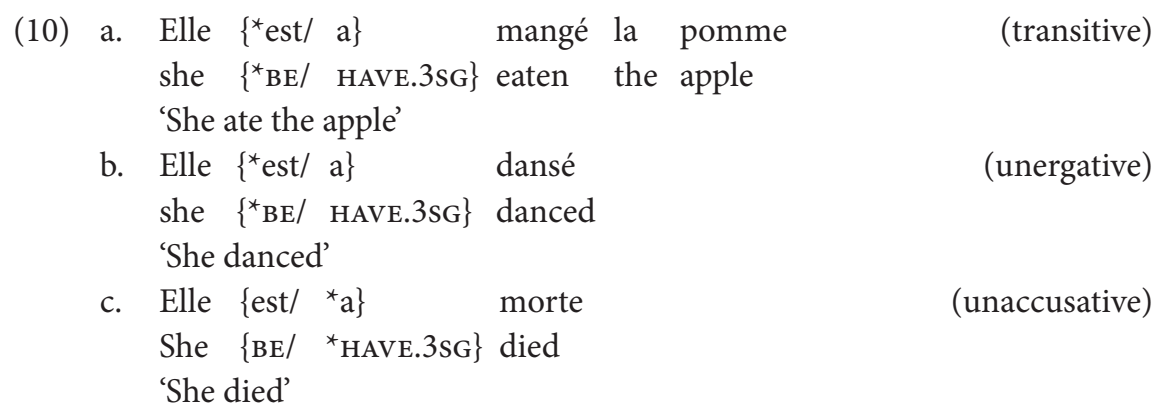

However, the extent to which 'be' co-occurs with unaccusatives varies across languages, suggesting that auxiliary selection is not merely a by-product of thematic or syntactic characteristics of monadic verbs (i.e. unergatives vs. unaccusatives). Sorace $(1993,2000)$, reviewing data from Germanic and Romance languages, noted that while auxiliary selection is variable across these languages, this variability is systematic. This is reflected in the Auxiliary Selection Hierarchy, which organizes unaccusatives into classes: (i): change of location, (ii) change of state, (iii) continuation of pre-existing state, (iv) existence of state, (v) uncontrolled process, (vi) controlled process. A language may opt for either auxiliary verb for a given class, but if it opts for 'be', then it will also select 'be' for classes higher in the hierarchy.

Bentley and Eythórsson (2004) examine a variety of Romance and Germanic languages to make further distinctions within the Auxiliary Selection Hierarchy based on aspectual notions of dynamicity, telicity, and stativity. Following Sorace (2000) they note that in French, verbs denoting a change of state do not uniformly select 'have' or 'be'. Auxiliary selection in this class is conditioned by the telicity of the verb. While all verbs in this class are dynamic and denote change, inherently telic verbs (e.g. naître 'to be born', mourir 'to die') select 'be', while others (e.g. croitre 'to grow', rougir 'to blush') select 'have'.

In passive constructions in the past tense, this distinction patterns similarly to the use of ser/estar in Spanish. In eventive passives denoting a one-time event, avoir is used in the passé compose - functionally equivalent to the preterit in Spanish - and is compatible with a by-phrase. In stative passives, être is used in the imperfect, and is not compatible with a by-phrase under a stative interpretation.

(11) a. Les pommes ont été mangés par la fille (eventive) the apples have been eaten by the girl 'The apples were eaten by the girl'
b. La porte était ouverte ( ${ }^{*}$ par la fille) (stative) the door was open by the girl 'The door was open (*by the girl)'


In both Spanish and French, knowledge of the event structure of predicates plays a pivotal role and has overt morphosyntactic consequences. Specifically, sensitivity to event boundaries is crucial. In Spanish, participial complements of estar must necessarily be inherently telic. In French, telicity is the determining factor in auxiliary selection with unaccusative verbs.

\section{Hypotheses and research questions}

The ser/estar distinction involves a complex interaction of several modules of the grammar (namely, syntax, lexicon, semantics, and discourse/pragmatics). As such, the learnability task for the acquisition of ser and estar, 'to be', is a complex one, requiring knowledge in distinct linguistic domains. The following areas need to be acquired:

- SYNTAX: The passive construction

- LEXICON: Choice of copula verb including use with corresponding canonical adjectives

- SEMANTics: Aspectual distinction between events and states

- Discourse/Pragmatics: Possibility of generic interpretation of the subject with ser but not estar.

Underlyingly, English, French and Spanish do not differ in any fundamental way in relation to the syntax of eventive passives. However, at the surface level Spanish forces a copula choice that is not available in English or French. Since there is no fundamental difference in the underlying structures for eventive passives, we do not expect any noticeable influence. However, since both English and French only have one copula and thus do not mark the eventive vs. stative passive distinction like Spanish does, we could envision that a possible influence from these languages would result in less accurate knowledge of copula choice in this context. Assuming ser is the unmarked choice because it does not carry aspectual features, our expectation is that properties relating to the copula ser will show less divergence from native controls than properties related to estar.

While there is no aspectual distinction via copula selection in French, there are other areas that are sensitive to aspect. Specifically, French has at least two properties to its grammar that English lacks, and which may offer bootstrapping effects for the properties we are examining. First, it marks the difference between inherent states via auxiliary selection in periphrastic perfect verbal constructions: être 'to be' is used with inherently telic unaccusatives, and avoir 'to have' elsewhere and (ii) similar to Spanish, it grammaticalizes (i.e. morphologically instantiates) perfective aspect in its past tenses. Thus we argue that bootstrapping from early 
acquisition of French aspectual features and auxiliary selection will give Canadian HSs an advantage for copula selection with eventive and stative passives. Crucially, for this argument to be valid our subject groups only differed in their knowledge of French, specifically, the Canadian HS group, and not the US group, were from the first grade ( $\sim 6$ years of age) onward in the French immersion stream. We return to this possibility in the discussion section once we see what the data reveal. If the Canadian and American HSs do differ from each other (as we expect), we predict that this difference will reflect better accuracy in general for the Canadians. With the aforementioned in mind, our research questions are as follows:

1. Will American- and Canadian-Spanish HSs be able to reliably determine if a passive is eventive or stative, correlating this to the type of copulas expected?

2. Given the fact that the Canadian-Spanish heritage group had L3 French as their language of instruction throughout their schooling and that the US-Spanish heritage group was, strictly speaking, Spanish/English bilingual, will knowledge of French be facilitative for the Canadian heritage group for this property?

\section{Previous research}

Previous research on copula choice in Spanish has shown that ser/estar copulas are subject to language change where both historical and individual change takes place by an overextension of the uses of estar (Silva-Corvalán, 1986; Geeslin, 2001, 2002a, 2002b; Silva-Corvalán \& Montanari, 2008; Geeslin \& Guijarro-Fuentes, 2008; Marco \& Marín, this volume). It is argued that this is because estar loses some of the features that distinguish it. Van Patten (1985) examined adult learners of L2 Spanish and showed that acquisition takes place through 5 stages. Geeslin (2001, 2002a, 2002b) argued that language loss/simplification, historical change and L2 acquisition of the copulas closely resemble each other. Geeslin and Guijarro-Fuentes (2005) studied groups of adult learners of L2 Spanish from three different L1 backgrounds, some with and some without copula choice. The authors argue that the L1 and indeed knowledge of additional languages did not seem to play a role.

The present study is based on original work from Bruhn de Garavito and Valenzuela (2008) that looked at the acquisition of eventive and stative passives in L2 Spanish (of L1 English speakers). In general, the L2 learners performed differently than native speakers, overextending the domain of estar. While L2 learners were able to distinguish between the copulas with adjectival complements, they showed more difficulty with passive constructions. This difficulty also extended 
to the interpretative properties of copula choice, where the L2 learners allowed a generic interpretation of the subject associated with estar in passives. Bruhn de Garavito \&Valenzuela suggest that the results of the L2 learners may stem from processing problems. While the L2 learners may have knowledge of the ser/estar distinction, as evidenced by the performance with adjectival complements, their use in a more complex syntactic environment (i.e. passive constructions, which involve additional syntactic movement) increases the processing load and results in an elevated rate of errors.

Bruhn de Garavito (2009) employed the same methods as Bruhn de Garavito and Valenzuela (2008) and examined an additional language pairing, L1 German/ L2 Spanish. Unlike English, German captures the stative/eventive difference in passive constructions via the systematic use of distinct verbs: sein 'to be' is used with statives and warden 'get' is used with eventive verbs. Like subjects of estar in Spanish, the subject of sein passives must be interpreted as specific. In spite of this apparent advantage, however, the L1 German group performed similarly to the L1 English group from Bruhn de Garavito and Valenzuela (2008). Bruhn de Garavito speculates that this performance might result from selective transfer of the L1 into the L2, questioning the often-assumed scenario of full transfer.

The present study builds on these works, but examines heritage speakers of Spanish. By testing these groups, we are able to look at any effect English may have on copula choice in Spanish, even when Spanish is a native language. Additionally, the heritage speakers from Canada also have knowledge of French, which exhibits some aspectually-conditioned morphological contrasts (i.e. past tense forms) that are similar to those found in Spanish. Although L1 German did not aid the learners in Bruhn de Garavito (2008), it may be the case that transfer from French facilitates or reinforces the uses of ser and estar for our Candian-heritage speakers. In the following section we give information about the participants in this study and detail the methods used.

\section{Methodology}

\subsection{Participants}

A total of 42 informants participated in this study. The participants' responses to a background questionnaire were used to classify them into one of the following three groups: (i) US Heritage Speaker group, (ii) Canadian Heritage Speaker group, and (iii) Spanish Control group. The US Heritage Speaker group included 22 college-age bilingual individuals from the state of Florida, USA. The countries of origin of the Spanish varieties were from various countries in Latin America 
(Colombia, Argentina, and Mexico). Although all of them reported having spoken Spanish at home from birth, their dominant language was English. The Canadian Heritage Speaker group was made up of 10 individuals who, in addition to English and Spanish, began learning French in kindergarten at the age of 5 . The average age of the Canadian group was 28 and, like the US group, had reported having spoken Spanish in the home since birth. Their dominant language was English. Also, like the US group, their countries of origin were from various countries in Latin America. Crucially, both HS groups had similar near-native proficiency in their Spanish. Finally, the control group was made up by 10 Spanish native speakers (from Spain and Colombia) residing in Canada. These control informants were L2 (adult) learners of English. All 42 informants were matched (to the extent that it was possible) for age, background, and general education levels.

\subsection{Tasks}

There were two tasks, an Acceptability Judgment Task and a Sentence Selection Task, which were the original tasks from Bruhn de Garavito and Valenzuela (2006, 2008). The acceptability judgment task assessed the use of ser and estar under various conditions: in (eventive and stative) passive constructions with or without an explicit agent, in canonical past tense situations (preterit/imperfect), and with adjectives. The sentence selection task assessed the interpretation of ser and estar in passive and adjectival constructions.

\subsubsection{Acceptability Judgment Task}

As previously discussed, the Acceptability Judgment Task aimed to assess use of ser and estar. Participants were asked to rate the acceptability of a given sentence in Spanish on a scale from 1 (totally unacceptable) to 5 (totally acceptable); there was a separate option ('I don't know') to indicate uncertainty. One set of target items tested for acceptability of each copula in a passive construction, with or without the expression of an agent. There were 5 items of each type, for a total of 20 items. Examples, with the expected grammaticality indicated, are given in (12)-(15) below.

(12) Ser, with agent, grammatical:

Aquí la comida es preparada por un cocinero profesional

here the food is SSER $\}_{\text {prepared by a chef professional }}$

'Here the food is prepared by a professional chef'

(13) Ser, without agent, grammatical:

En esta compañía las oficinas son pintadas cada verano

in this company the offices $\operatorname{are}_{\{S E R\}}$ painted each summer

'In this company the offices are painted each summer' 
(14) Estar, with agent, ungrammatical:

${ }^{*}$ Las tareas ya están completadas por los alumnos
the homeworks already are EESTAR $_{\text {c completed by the students }}$ com the students'
'The homework is already completed by the

(15) Estar, without agent, grammatical:
La cena ya está preparada para la fiesta
the dinner already is ${ }_{\{\mathrm{ESTAR}\}}$ prepared for the party
'The dinner for the party is already prepared'

Another set of target items in this task examined acceptability of each copula in the past tense. Unlike English (but like French), Spanish verbs in the past tense are inflected for grammatical aspect (i.e., perfective or imperfective aspect). While each copula may be used with either aspectual marking, there is a preference for stative passives (compatible with estar) to be expressed with the imperfect and eventive passives (compatible with ser) to be expressed with the preterit. There were 5 test items for each passive and aspect combination, for a total of 20 items. Examples, along with expected acceptability, are given in (16)-(19) below.

(16) Ser, preterit, preferred:

El libro fue escrito en Inglaterra

the book was $_{\{\text {SER }\} \text { pret }}$ written in England

'The book was written in England'

(17) Estar, preterit, dispreferred:

\#La carne estuvo quemada en la parrilla

the meat was(ESTAR)pret burned on the grill

'The meat was burned on the grill'

(18) Ser, imperfect, dispreferred:

\#El libro era escrito en inglés

the book was(SER)imp written in English

'The book was written in English'

(19) Estar, imperfect, preferred:

El edificio estaba construido con ladrillos importados

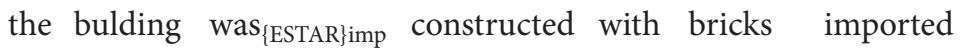

'The bulding was constructed with imported bricks'

The final set of target items assessed knowledge of adjectival constructions using adjectives that were permissible with only one of the two copular verbs. Each copula was paired with both acceptable and unacceptable adjectives. There were 5 of each item type, for a total of 20 items. Examples are given in (20)-(23) below. 
(20) Estar + adjective, grammatical:

El vaso está lleno de agua

the vase is \{ESTAR $\}_{\text {full of water }}$

'The vase is full of water'

(21) Estar + adjective, ungrammatical:

${ }^{*}$ El entrenador de fútbol es satisfecho

the coach of football is iESTAR\} $_{\text {satisfied }}$

'The football coach is satisfied'

(22) Ser + adjective, grammatical:

El nuevo trabajador es muy ${ }^{4}$ capaz

the new worker is \{SER $\}_{\text {very capable }}$

'The new worker is very capable'

(23) Ser + adjective, ungrammatical:

*El gato de Luisa está leal

the cat of Luisa is ${ }_{\{S E R\}}$ loyal

'Luisa's cat is loyal'

In sum, there were 60 target items on the Acceptability Judgment Task.

\subsubsection{Sentence Selection Task}

The Sentence Selection Task was designed to test participants' knowledge of the interpretive properties that each copula assigns to its subject. In this task, a context was provided, followed by four options. Participants were asked to indicate which of the four options was most appropriate given the context. The options for each item were (i) a sentence containing ser, (ii) the same sentence with estar, (iii) a choice of both sentences, or (iv) a choice indicating that neither sentence was acceptable. As previously mentioned, only ser can have a subject with a generic interpretation. Items varied in both the interpretation forced by each context (generic or not) as well the type of complement to the copula (adjectival or passive). There were 5 items for each combination of context and complement, for a total of 20. Examples are given in (24)-(27) below, first in Spanish and then in English, with expected answer marked in italics.

(24) Non-generic context with adjective:

Luisa y Guillermo están en el partido final del campeonato de fútbol en el que juega su equipo favorito. Suelen ir a todos los partidos pero hoy Luisa no lo está pasando bien porque...

4. As one of the reviewers points out, the presence of muy is necessary for grammaticality here. These modifiers were controlled across instruments. 

a. Los fanáticos son violentos
b. Los fanáticos están violentos
c. Ni a ni b
d. Ambas, a y b

Luisa and Guillermo are at the final game of the football championship in which their favorite team is playing. They usually go to all the games but today Luisa is not having a good time because ...
a. The fans are $(\mathrm{SER})$ violent
b. The fans are $_{(E S T A R)}$ violent
c. Neither a nor b
d. Both, a and $b$

(25) Generic context with adjective:

Enrique y Paquita están hablando de deportes. Enrique dice que le gustan todos los deportes menos el fútbol. Paquita está sorprendida y le pregunta por qué. Enrique dice:
a. Los fanáticos son violentos
b. Los fanáticos están violentos
c. Ni a ni b
d. Ambas, a y b

Enrique and Paquita are talking about sports. Enrique says that he likes all sports except football. Paquita is surprised and asks him why. Enrique says:
a. The fans are $_{(S E R)}$ violent
b. The fans are (ESTAR) $_{\text {violent }}$
c. Neither a nor b
d. Both, $a$ and $b$

(26) Non-generic context with passive:

Lucía está muy enojada. Esperaba una buena taza de café al llegar a casa. Lucía dijo:
a. ¿Por qué no es servido el café?
b. ¿Por qué no está servido el café?
c. Ni a ni b
d. Ambas, a y b

Lucía is very angry. She expected a good cup of coffee when she got home. Lucía said:
a. Why isn't $\mathrm{t}_{(\mathrm{SER})}$ the coffee served?
b. Why isn't ${ }_{(E S T A R)}$ the coffee served?
c. Neither a nor b
d. Both, $a$ and $b$ 
(27) Generic context with passive:

Patricia pidió una taza de té a la inglesa. No quiso tomárselo. Patricia dijo:
a. En Inglaterra el té es servido sin azúcar
b. En Inglaterra el té está servido sin azúcar
c. Ni a ni b
d. Ambas, a y b

Patricia asked for a cup of tea English style. She wouldn't drink it. Patricia said:
a. In England tea is (SER) $_{\text {served without sugar }}$
b. In England tea is (ESTAR) served without sugar
c. Neither a nor b
d. Both, $a$ and $b$

\section{Results}

\subsection{Acceptability Judgment Task}

We will now turn to the results for the Acceptability Judgment Task. A mixedmodel ANOVA was used for the statistical analysis of the participants' Likert scores (i.e. the sum of the ratings for each item type). Some of the data points were numerically transformed to facilitate the interpretation of the statistical results. This was achieved by reversing the scale of the ungrammatical ${ }^{5}$ items such that a rating of 5 indicated unacceptability and 1 indicated acceptability: a rating of 1 became 5, 2 became 4, 3 remained 3, etc., for the ungrammatical items only. By doing this, the "expected" rating for each item type is 5, regardless of grammaticality. The interpretation of comparisons between item types is more intuitive, particularly between grammatical and ungrammatical items, where no significant differences are expected. The findings are first presented in graph form in Figures 1 to 3 below.

The mixed-model ANOVA showed main effects for $\operatorname{Group}(F(2,39)=17.78$, $\mathrm{p}<.001)$ and Condition $(\mathrm{F}(11,429)=14.36, \mathrm{p}<.001)$, and a Group ${ }^{\star}$ Condition interaction $(\mathrm{F}(22,429)=6.00, \mathrm{p}<.001)$. Planned contrasts assessed the effects of grammaticality, the verb used (ser or estar), and the construction type (passive, past tense, and adjectival complements) within groups, as well as differences between groups. All comparisons were done using False Discovery Rate control (Benjamini \& Hochberg, 1995).

5. When reporting our results, we use 'grammaticality' to mean the general acceptability of an item type, based on claims from the literature; i.e. 'grammatical' items are both those which are categorically permitted as well as those which are preferentially accepted. 


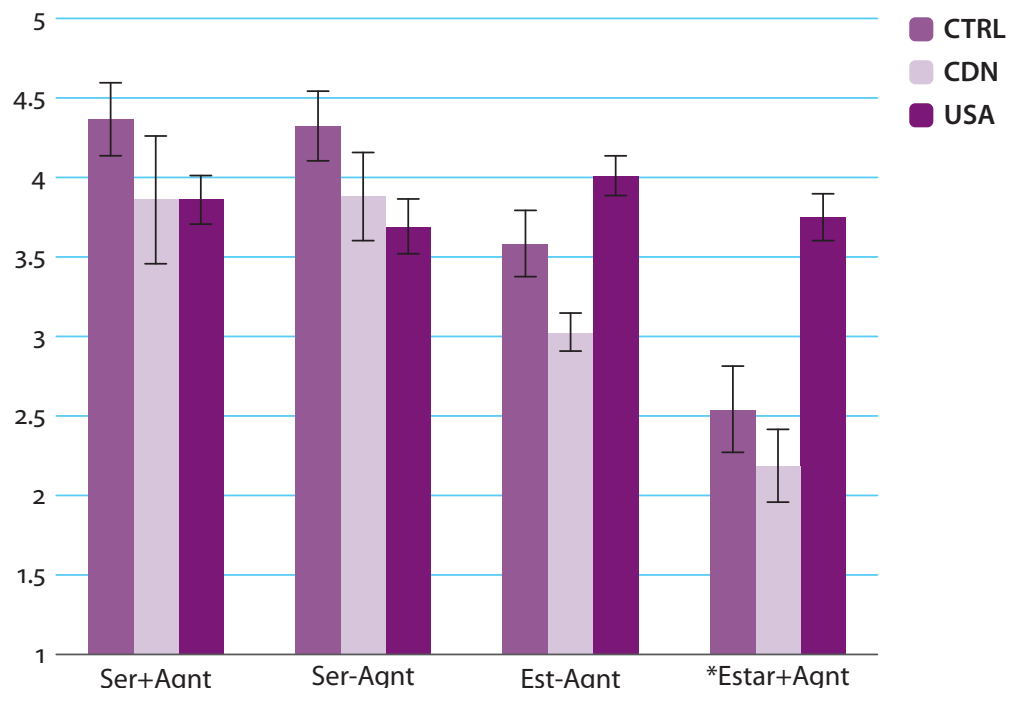

Figure 1. Acceptability Judgment Task average rating: Passives.

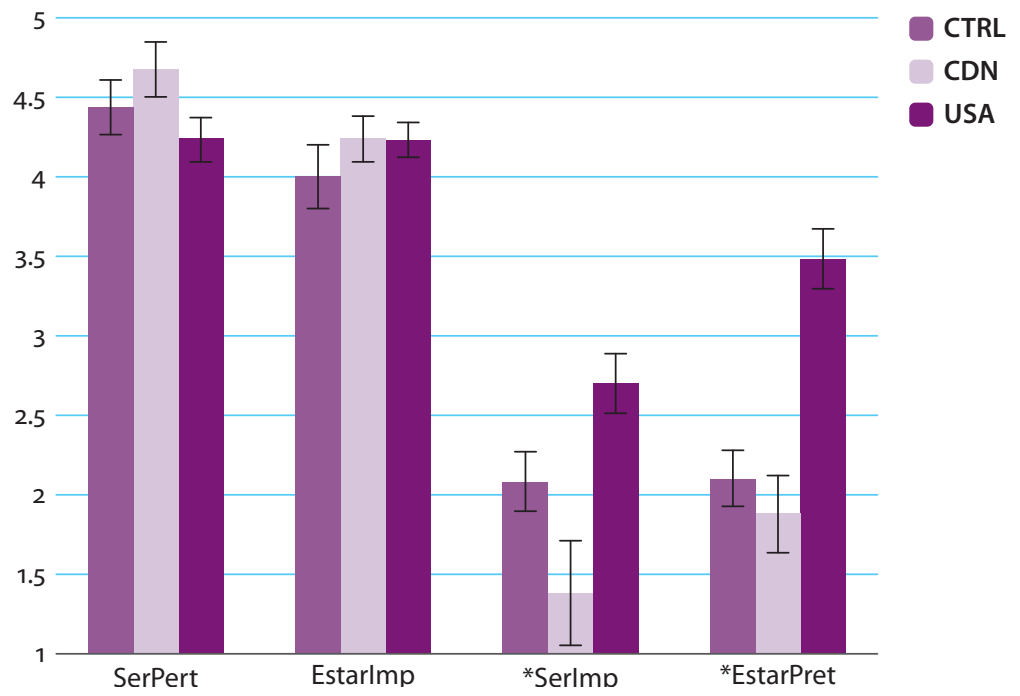

Figure 2. Acceptability Judgment Task average rating: Past Tense. 


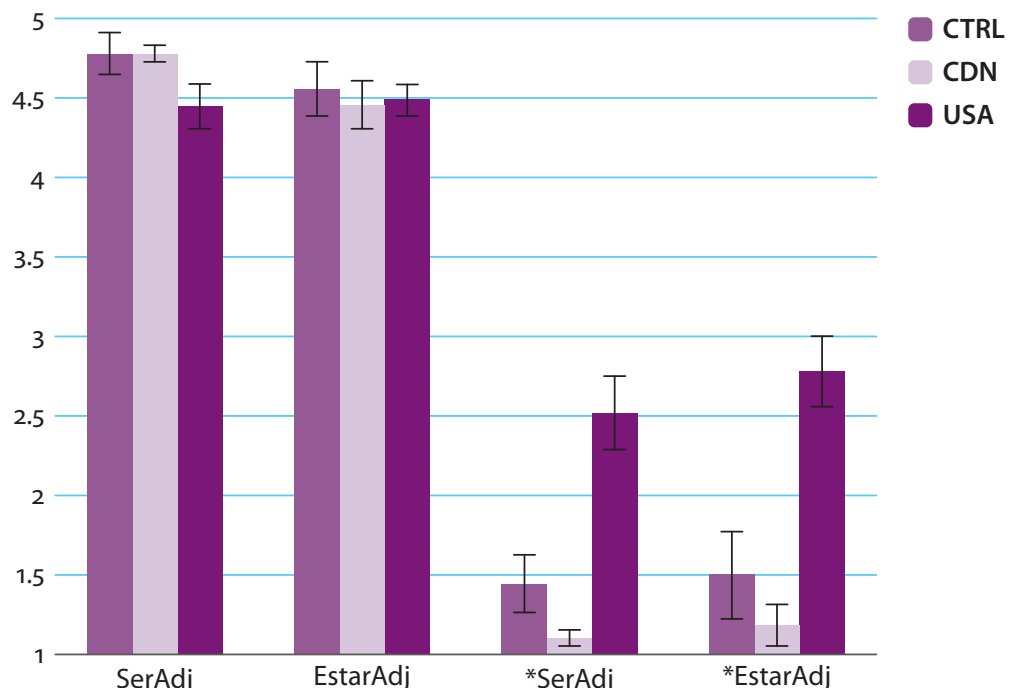

Figure 3. Acceptability Judgment Task average rating: Adjectival Complements.

First, we examine intragroup comparisons. The control group showed no significant difference between grammatical and ungrammatical items $(\mathrm{p}=.091)$, suggesting equally extreme ratings for both of these item types. The difference between these item types was significant for the Canadian group $(p=.014)$, who were more likely to assign (correct) extreme ratings to ungrammatical items than to grammatical items. This comparison was also significant for the US group $(p<.001)$, but in the opposite direction: this group was more likely to assign extreme ratings to grammatical items than to ungrammatical items. All groups fared better on ser items compared to estar items (Control: $\mathrm{p}=.002$; Canadian: $\mathrm{p}=.004$; US: $\mathrm{p}<.001$ ). All groups performed better with adjectival complements as compared to passives (Control: $\mathrm{p}<.001$; Canadian: $\mathrm{p}<.001$; US: $\mathrm{p}<.001$ ) or past tense items (Control: $\mathrm{p}=.001$; Canadian: $\mathrm{p}=.042$; US: $\mathrm{p}=.002)$. The Canadian group performed better with past tense items than passive items $(\mathrm{p}<.001)$, but there were no differences for the Control $(\mathrm{p}=.392)$ or US $(\mathrm{p}=.260)$ groups here.

Next, we turn to between-group comparisons. The Canadian group did not differ significantly from the controls for any item type $(\mathrm{p}>.114$ for all comparisons). The US group performed significantly lower than the Control group on four of the five ungrammatical item types: estar + agent $(\mathrm{p}=.002)$, estar + preterit $(\mathrm{p}<.001),{ }^{\star} \operatorname{ser}+\operatorname{adj}(\mathrm{p}=.001)$, and ${ }^{\star}$ estar $+\operatorname{adj}(\mathrm{p}<.001)$ conditions. They also performed significantly lower than the Canadian group in these conditions $(p<.001$ for all comparisons), as well as the ser + imperfect condition $(\mathrm{p}<.001)$. The US group did, however, outperform the Canadian group in the estar + agent condition $(p=.002)$. There were no significant differences for any other comparisons. 


\subsection{Sentence Selection Task}

For this task, participants' responses were coded as either correct or incorrect, and the results were analysed using a generalized estimating equations (GEE) approach (Zeiger \& Liang, 1986), which allows for the treatment of dichotomous, correlated data. The analysis indicated significant main effects for Group (Wald $\chi^{2}=11.518 ; \mathrm{df}=2 ; \mathrm{p}=.003$ ) and Condition (Wald $\chi^{2}=67.417 ; \mathrm{df}=5 ; \mathrm{p}<.001$ ), and a significant Group ${ }^{\star}$ Condition interaction (Wald $\chi^{2}=23.396 ; \mathrm{df}=10 ; \mathrm{p}=.009$ ). Planned comparisons testing for both within-group and between-group differences were done using False Discovery Rate control.

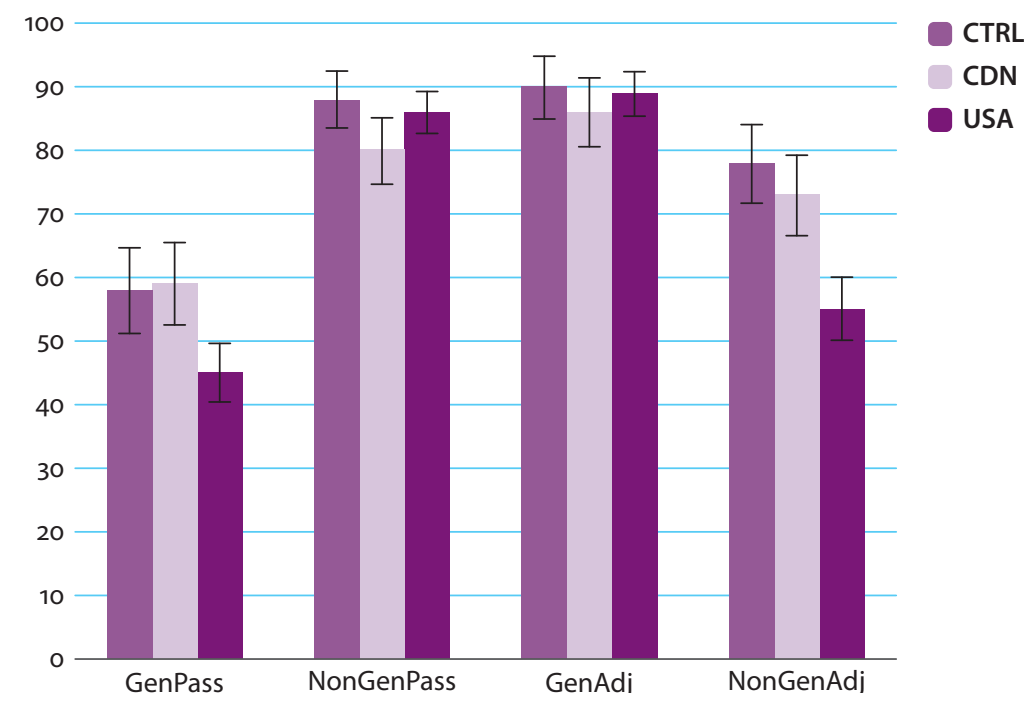

Figure 4. Sentence Selection Task: \% accuracy.

The intragroup comparisons examined both context (i.e. generic or not) and structure type (i.e. passive or adjectival) for any relevant patterns. The US group showed the most interesting pattern. This group performed better with generic, adjectival items than both non-generic, adjectival items $(\mathrm{p}<.001)$ and generic, passive items $(\mathrm{p}<.001)$. They also performed better with non-generic, passive items than with generic, passive items $(\mathrm{p}<.001)$ and non-generic, adjectival items $(\mathrm{p}<.001)$. No other comparisons for this group were significant. These results, considered simultaneously, indicate that the participants in this group more often selected ser when confronted with adjectival items and estar when faced with passive constructions. The Control group performed significantly differently with generic, passive items than with both non-generic, passive items ( $\mathrm{p}=.005)$ and generic, adjectival items $(\mathrm{p}=.001)$; however, no other comparisons were significant, and the pattern seen in the US group is not suggested here. There were no significant comparisons for the Canadian group. 
Similar to the first task, the Canadian group did not differ from the Control group for any item type. The US group differed significantly from the Control group only on non-generic, adjectival items $(\mathrm{p}=.014)$, performing more poorly. The Canadian group also outperformed the US group in this condition ( $\mathrm{p}=.007)$. There were no other significant differences between groups.

\section{Discussion}

To start the discussion of what the main results of the two empirical tasks can tell us when brought together, it is useful to revisit our guiding research questions and hypotheses. Our research questions asked whether or not the two HS groups would show differences from the control groups (and from each other) in regard to (i) knowledge of stative and eventive passives and (ii) their mappings to particular copula. We anticipated the possibility that both HS groups would differ from the controls but also hypothesized that if one of the groups were to be more similar to the controls, it would be the Canadian HSs for reasons enumerated above and to be fleshed out below. We also hypothesized that HS differences would be visible with the selection of estar, which can also be viewed as an expansion of its domain of use. Since estar is the copula with aspectual features, one possible explanation is that English influence results in the erosion of these aspectual properties thus opening the possibility of its use to more contexts (i.e. contexts in which its inherent aspectual features become inert).

Turning to a summary of the results of the two tasks, considered together, the data revealed an asymmetry among the three groups. The US group performed distinctly from the control group. The results suggest that this group allows for a broader use of estar than the other groups, as they consistently failed to reject unacceptable uses of estar in the acceptability judgment task and, in the sentence selection task, indicated estar as a viable option in a context in which it is ungrammatical (i.e. passive constructions in a generic context). Additionally, this group showed, at best, indeterminate knowledge of ser and its associated adjectival complements, failing to (strongly) reject ser with an ungrammatical adjectival complement in the acceptability judgment task and failing to rule it out as a viable option in infelicitous contexts with adjectival complements in the sentence selection task. In contrast with the US group's performance, the Canadian group matched the performance of the control group for all item types on both tasks.

With this summary in mind, it seems that the answer to our research questions is that it is not impossible for HSs to match the controls, but it does not seem to be the case that both groups do so. Our prediction that the Canadian HSs would be the group to be more consistent with the controls, if an asymmetry between 
the two groups of HSs were to arise, came to bear. In light of the differences across Canadian and US HSs, we need to look further into the possible variables that couple together to explain this difference. If indeed it is the case that influence from English is the cause for the changing nature of estar in the HS grammar, then one could ask why this is not true in the case of Canadian HSs of Spanish, who are also dominant speakers of English. It is possible, in fact likely, that important sociolinguistic differences pertaining to the status of Spanish in Canada and the United States respectively and its many implications for language maintenance bring something to bear here. Since we cannot comment directly on differences between the Canadian and US sociolinguistic contexts for Spanish and its relationship to this domain of grammar for these particular HSs, we will focus on the obvious linguistic differences that distinguish these HSs. As discussed above and throughout, the Canadian HSs are highly proficient L2 learners of French who acquired French in an immersion schooling context. This means that $50 \%$ of their education was conducted via the medium of French and started at a very young age (age 5). Since this is started at such a young age in the Canadian context, it is fair to say that their exposure to French began while their Spanish grammar was still developing, at least in certain domains of grammar. This also means that, differently from the US HSs, the drastic reduction in the home language that cooccurs with the onset of schooling in the typical case of HSs was divided between two languages, one of which is a Romance language. Again if English is the likely source of influence for the loss of aspectual features associated with estar, then receiving much less English input in the case of the Canadian HSS had a beneficial effect for their Spanish development and/or maintenance. So, it might be the case that community supported bilingualism/biliteracy, as is the case with English and French in Canada and its schooling system, can ameliorate language loss for HSs of yet another (heritage) language by virtue of the reduction in quantity of input exposure to a singular majority societal language as compared to a monolingual societal environment like the US. In other words, Canadian HSs are different and more like the controls because their Spanish does not have the same opportunities to develop differently.

It is not clear, however, that this above scenario is universal. That is, would all childhood bilingualism with biliteracy have the same positive effect we seem to have uncovered? Or perhaps, does it have more to do with the fact that the other language is French (or at least a language that provides some linguistic properties within its grammar that possibly provide bootstrapping support for the maintenance of the relevant properties)? What is it in the French grammar that could be making the difference we see? We noted that both English and French have one copula that corresponds to the two of Spanish. Knowledge of French might help the Canadian group in two ways: on the one hand, it provides (some) dedicated 
aspectual morphology, which means that perfective aspect is grammaticalized somewhere in the grammar as a syntactic feature, which is the feature relevant for estar. In addition to this, French displays the avoir/être distinction to form the periphrastic verb tenses that delineate inherent states (e.g., unaccusatives), meaning they have a (consistent) lexical/auxiliary distinction conditioned by a complement. Combining these two factors could make the Canadians more sensitive to or able to retain the contrastive properties for ser and estar as it relates to eventive and stative passives.

Of course, determining if there is a general effect for additional bilingualism and biliteracy on HS competence outcomes or whether such an effect is conditioned by the properties of the languages examined is an open empirical question. Given the linguistic landscape of the world, it would not be too hard to test its latent predictions. Bringing together HSs of the same languages in different national contexts is an important endeavour. It will allow us to continue to understand what the sources of HS differences are and what they cannot be. Studies like this one further demonstrate the dynamic nature of HS acquisition and the challenges the field faces at trying to provide descriptive and explanatory adequacy. One cannot speak of Spanish as a heritage language with any sense of macro-categorization, but rather HS Spanish (or any language, of course) acquisition within a particular language environment.

\section{References}

Beaudrie, S., \& Fairclough, M. (Eds.) (2012). Spanish as a heritage language in the US: State of the field. Washington, DC: Georgetown University Press.

Benjamini, Y., \& Hochberg, Y. (1995). Controlling the false discovery rate: A practical and powerful approach to multiple testing. Journal of the Royal Statistical Society. Series B, 57(1), 289-300.

Benmamoun, E., Montrul, S., \& Polinsky, M. (2013). Heritage languages and their speakers: Opportunities and challenges for linguistics. Theoretical Linguistics, 39, 129-181.

Bentley, D., \& Eythórsson, T. (2004). Auxiliary selection and the semantics of unaccusativity. Lingua, 114, 447-471. DOI: 10.1016/S0024-3841(03)00068-8

Bley Vroman, R. (1983). The comparative fallacy in interlanguage studies: The case of systematicity. Language learning, 33(1), 1-17. DOI: 10.1111/j.1467-1770.1983.tb00983.x

Bruhn de Garavito, J. (2009). Eventive and stative passives: The role of transfer in the acquisition of ser and estar by German and English L1 speakers. In J. Collentine et al. (Eds.), Selected Proceedings of the 11th Hispanic Linguistics Symposium (pp. 27-38). Somerville, MA: Cascadilla Proceedings Project.

Bruhn de Garavito, J., \& Valenzuela, E. (2008). Eventive and stative passives in Spanish L2 acquisition: A matter of aspect. Bilingualism: Language and Cognition, 11(3), 323-336. DOI: $10.1017 /$ S1366728908003556 
Bruhn de Garavito, J., \& Valenzuela, E. (2006). The status of ser and estar in late and early bilingual L2 Spanish. In C. Klee \& T. Face (Eds.), Selected Proceedings of the 7th Conference on the Acquisition of Spanish and Portuguese as First and Second Languages (pp. 100-109). Somerville, MA: Cascadilla Proceedings Project.

Camacho, J. (2012). Ser and estar: Individual/stage level predicates or aspect? In J. I. Hualde, A. Olarrea \& E. O'Rourke (Eds.), The handbook of hispanic linguistics (Blackwell handbooks in linguistics) (pp. 453-476). Oxford, England: Wiley-Blackwell. DOI: $10.1002 / 9781118228098 . \operatorname{ch} 22$

Carrasco, A, \& Fernández, L. (2006). Diccionario de perífrasis verbales. Madrid: Gredos.

Clements, C. (1988). The semantics and pragmatics of the Spanish < copula+ adjective > construction. Linguistics 26(5), 779-822.

Delbecque, N. (1997). The Spanish copulas SER and ESTAR. In M. Verspoor, K.D. Lee \& E. Sweetser (Eds.), Lexical and Syntactical constructions and the Construction of Meaning: Proceedings of the Bi-annual ICLA Meeting (pp. 247-270). Amsterdam, The Netherlands: John Benjamins. DOI: 10.1075/cilt.150.19del

Falk, J. (1979). Ser y estar con atributos adjetivales: anotaciones sobre el empleo de la cópula en catalán y en castellano. Stockholm, Sweden: Almqvist \& Wiksell International.

Geeslin, K. L. (2002a). The acquisition of Spanish copula choice and its relationship to language change. Studies in Second Language Acquisition, 24(3), 419-451.

DOI: $10.1017 /$ S0272263102003030

Geeslin, K. L. (2002b). Semantic transparency as a predictor of copula choice in second language acquisition. Linguistics: An Interdisciplinary Journal of the Language Sciences, 40(2), 439-446.

Geeslin, K. L. (2001). Changing norms, moving targets and the SLA of copula choice. Spanish Applied Linguistics, 5(1-2), 29-55.

Geeslin, K. L., \& Guijarro-Fuentes, P. (2008). Variation in contemporary Spanish: Linguistic predictors of estar in four cases of language contact. Bilingualism: Language and Cognition, 11(3), 365-380. DOI: 10.1017/S1366728908003593

Geeslin, K. L., \& Guijarro-Fuentes, P. (2005). The acquisition of copula choice in instructed Spanish: The role of individual characteristics. In D. Eddington (Ed.), Studies in the Acquisition of the Hispanic Languages: Papers from the 6th Conference on the Acquisition of Spanish and Portuguese as First and Second Languages (pp. 66-77). Somerville, MA: Cascadilla Proceedings Project.

Gumiel-Molina, S., \& Pérez-Jiménez, I. (2012). Aspectual composition in <ser/estar + adjective> structures: Adjectival scalarity and verbal aspect in copular constructions. Borealis: An International Journal of Hispanic Linguistics, 1, 33-62. Retrieved from $<$ http://septentrio. uit.no/index.php/borealis/article/view/2321/2166> DOI: 10.7557/1.1.1.2321

Kaltsa, M., Tsimpli, I., \& Rothman J. (2012). Syntax-discourse phenomena in heritage speakers and first language attriters: evidence from pronominal resolution (Unpublished manuscript). Presented at Wuppertal Workshop on Heritage Languages. Aristotle University of Thessalonik and University of Reading. Wuppertal, Germany: October, 4-6, 2012.

Lema, J. (1992). Distinguishing copular and aspectual auxiliaries: Spanish ser and estar. In J. Amastae, G. Goodall, M. Montalbetti \& P. Phinney (Eds.), Contemporary research in Romance linguistics (pp. 257-274). Amsterdam, The Netherlands: John Benjamins.

Leonetti, M. (1994). Ser y estar: estado de la cuestión. Barataria, 1, 182-205.

Levin, B., \& Rappaport, M. (1986). The formation of adjectival passives. Linguistic Inquiry, 17(4), 623-661. 
Luján, M. (1981). The Spanish copulas as aspectual indicators. Lingua, 54, 165-210. DOI: $10.1016 / 0024-3841(81) 90068-1$

Maienborn, C. (2005). A discourse-based account of Spanish ser/estar. Linguistics, 43(1), 155180. DOI: 10.1515/ling.2005.43.1.155

Montrul, S. (2008). Incomplete acquisition in bilingualism: Re-examining the age factor. Amsterdam, The Netherlands: John Benjamins. DOI: 10.1075/sibil.39

Montrul, S. (2004). Subject and object expression in Spanish heritage speakers: A case of morphosyntactic convergence. Bilingualism: Language and Cognition, 7(2), 125-142.

DOI: $10.1017 / S 1366728904001464$

Pascual y Cabo, D., \& Rothman, J. (2012). The (il)logical problem of heritage speaker bilingualism and incomplete acquisition. Applied Linguistics, 33(4), 450-455.

DOI: 10.1093/applin/ams037

van Patten, B. (1985). The acquisition of ser and estar in adult second language learners: A preliminary investigation of transitional stages of competence. Hispania, 68, 399-406. DOI: $10.2307 / 342218$

Pires, A., \& Rothman, J. (2009). Disentangling sources of incomplete acquisition: An explanation forcompetence divergence across heritage grammars. International Journal of Bilingualism, 13(2) 211-238. DOI: 10.1177/1367006909339806

Polinsky M. (2011). Reanalysis in adult heritage language: A case for attrition. Studies in Second Language Acquisition, 33, 305-328. DOI: 10.1017/S027226311000077X

Polinsky, M. (2008). Russian gender under incomplete acquisition. The Heritage Language Journal, 6(1), 40-70.

Polinsky, M. (2007). Incomplete acquisition: American Russian. Journal of Slavic Linguistics, $14,191-262$.

Roby, D. B. (2009). Aspect and the categorization of states: The case of ser and estar in Spanish. Amsterdam, The Netherlands: John Benjamins. DOI: 10.1075/slcs.114

Rothman, J. (2009). Understanding the nature and outcomes of early bilingualism: Romance languages as heritage languages. International Journal of Bilingualism, 13(2), 155-164.

DOI: $10.1177 / 1367006909339814$

Rothman, J. (2007). Heritage speaker competence differences, language change and input type: Inflected infinitives in heritage Brazilian Portuguese. International Journal of Bilingualism, 11(4), 359-389. DOI: $10.1177 / 13670069070110040201$

Rothman, J., \& Treffers-Daller, J. (2014). A prolegomenon to the construct of the native speaker: Heritage speaker bilinguals are natives too! Applied Linguistics, 35(1), 93-98.

DOI: 10.1093/applin/amt049

Schmitt, C. (1992). Ser and estar: A matter of aspect. In NELS 22 Proceedings of the North East Linguistic Society (pp. 411-425). Amherst, MA: GLSA Publications.

Schmitt, C., \& Miller, K. (2007). Making discourse-dependent decisions: The case of the copulas ser and estar in Spanish. Lingua, 117(11), 1907-1929. DOI: 10.1016/j.lingua.2006.11.007

Silva-Corvalán, C. (1994). Language contact and change: Spanish in Los Angeles. Oxford, England: Clarendon Press.

Silva-Corvalán, C. (1986). Bilingualism and language change: The extension of estar in Los Angeles Spanish. Language, 62, 587-608. DOI: 10.1353/lan.1986.0023

Silva-Corvalán, C., \& Montanari, S. (2008). The acquisition of ser, estar (and be) by a SpanishEnglish bilingual child: The early stages. Bilingualism: Language and Cognition, 11(03), 341-360. DOI: 10.1017/S136672890800357X 
Sorace, A. (2011). Pinning down the concept of "interface" in bilingualism. Linguistic Approaches to Bilingualism, 1(1), 1-33. DOI: 10.1075/lab.1.1.01sor

Sorace, A. (2004). Native language attrition and developmental instability at the syntax-discourse interface: Data, interpretations and methods. Bilingualism: Language and Cognition, 7(2), 143-145. DOI: $10.1017 /$ S1366728904001543

Sorace, A. (2000). Syntactic optionality in non-native grammars. Second Language Research, 16(2), 93-102. DOI: 10.1191/026765800670666032

Sorace, A. (1993). Incomplete and divergent representations of unaccusativity in non-native grammars of Italian. Second Language Research, 9, 22-48. DOI: 10.1177/026765839300900102

Vañó-Cerdá, A. (1982). Ser y estar + adjetivos: un estudio sincrónico y diacrónico. Tubingen, Germany: Narr.

Varela, S. (1992). Verbal and adjectival participles in Spanish. In C. Laeufer \& T. A. Morgan (Eds.), Theoretical analyses in romance linguistics (pp. 219-234). Amsterdam, The Netherlands: John Benjamins.

Zagona, K. (2013). Tense, aspect and modality. In M. den Dikken (Ed.), Encyclopedia of generative syntax. Cambridge, England: Cambridge University Press.

Zagona, K. (2012). Ser and estar: Phrase structure and aspect. In C. Nishida \& C. Russi (Eds.), Building a bridge between linguistic communities of the Old and the New World, Cahiers Chronos, 25 (pp. 303-327). Amsterdam, The Netherlands and New York, NY: Rodopi.

Zeiger, S. L., \& Liang, K. Y. (1986). Longitudinal data analysis for discrete and continuous outcomes. Biometrics, 42, 121-130. DOI: 10.2307/2531248 